The University of Akron

\title{
IdeaExchange@UAkron
}

Proceedings from the Document Academy

University of Akron Press Managed

December 2018

\section{Why Are We Here? On the (Philosophical) Value of Documents}

\author{
Marco Inchingolo \\ University of Turin, m.inchingolo@gmail.com \\ Valeria Martino \\ University of Turin, valeriamartino92@gmail.com
}

Please take a moment to share how this work helps you through this survey. Your feedback will be important as we plan further development of our repository.

Follow this and additional works at: https://ideaexchange.uakron.edu/docam

\section{Recommended Citation}

Inchingolo, Marco and Martino, Valeria (2018) "Why Are We Here? On the (Philosophical) Value of Documents," Proceedings from the Document Academy: Vol. 5 : Iss. 2 , Article 1.

DOI: https://doi.org/10.35492/docam/5/2/1

Available at: https://ideaexchange.uakron.edu/docam/vol5/iss2/1

This Editorial is brought to you for free and open access by University of Akron Press Managed at IdeaExchange@UAkron, the institutional repository of The University of Akron in Akron, Ohio, USA. It has been accepted for inclusion in Proceedings from the Document Academy by an authorized administrator of

IdeaExchange@UAkron.For more information, please contact mjon@uakron.edu, uapress@uakron.edu. 
What does a philosopher do with documents? The most natural answer to this question would probably be that philosophers, as writers, produce documents, i.e., books, academic papers, transcripts and videos conferences, etc.

This is basically the commonsensical intuition about the philosopher's job. What would appear as less intuitive, though, is a philosopher producing documents about documents - that is, writing books and conducting research about the nature of documents and documentary practices in general.

Indeed, this seems to be the kind of issue other disciplines like archeology, history, museum studies, the communication and information sciences, and media and documentation studies would care about.

But this would be a huge mistake. Philosophy - and in particular ontology-has always been interested in what there is out there in the world. And documents are a peculiar class of objects, the stuff the world is filled with.

As a consequence of this, questions like "What is a document?" and "What kind of role do they play in our human society?" can legitimately appear in a philosopher's agenda.

This preliminary gloss about the relationship between philosophy and documents is not only due to a mere autobiographical concern, as in fact this year the Annual Meeting of the Document Academy has been hosted by a philosophy department for the first time: by the Department of Philosophy of the University of Turin. It was also meant to illustrate at least two core aspects of this annual meeting:

- the intrinsically interdisciplinary aim of the conference

- the fruitful cross-fertilization among diverse disciplines driven by a common interest

It was a real pleasure - at least for those of us writing this introduction - to see a scholar in the field of law taking notes during a talk about ethnomusicology or a philosopher asking questions about information management. This is not such a common thing in academia. Therefore it seems utterly appropriate to us to draw our attention on this aspect in these short introductory considerations. With this, we do not want to claim that interdisciplinarity per se is an added value. What we do want to claim, though, is that in the case of the Document Academy, interdisciplinarity embodies not only a goal, but a constitutive feature of documentrelated disciplines.

It is impossible, indeed, to understand the value of documents among human societies without being aware and taking into account the manifold ramifications through which this special class of objects unfolds its potential. 
This annual meeting was a virtuous attempt — and, we would say, also a successful one- to uphold the methodological values of document studies we briefly sketched out in the above lines. The topic of the 2018 edition of Docam was The Documedia Revolution. This reflected the will to highlight the immense and ever-growing importance of documents nowadays.

The idea at the basis of The Documedia Revolution is that we are witnessing an overabundance of documents - especially thanks to the new media, and in particular the web. These new media produce considerable changes in the production, retention, and use of documents and therefore in the disciplines dealing with them.

This could lead us to question what differences exist, if any, between old and new documents, or old and new documentary practices.

Beside these more theoretical approaches, one might also decide to take into account more practical issues related to the new possibilities opened up by the documentary revolution and investigate how this might affect our habits, values, beliefs, and so on.

Furthermore, one might also address the ethical and legal side of the document story by inspecting which might be the moral and ethical values of documents. For instance: what can and cannot be, what should or should not be documented.

With no doubts, this is a short and severely partial sketch of a possible agenda for document studies. But it is already a challenging, absorbing, and tremendously fascinating one.

The contributions that follow in the present proceedings could therefore be taken as different attempts at opening paths in the protean and dense field of documents. 